\title{
Uncommon species diversity values in epiphytic diatom assemblages of the kelp Eisenia arborea
}

\section{Valores poco comunes de diversidad de especies en asociaciones de diatomeas epifitas del kelpo Eisenia arborea}

\author{
David A. Siqueiros Beltrones ${ }^{1}$, Uri Argumedo Hernández ${ }^{2}$ and Cristina Landa Cansigno ${ }^{3}$ \\ 'Departamento de Plancton y Ecología Marina, Centro Interdisciplinario de Ciencias Marinas del Instituto Politécnico Nacional. Av. IPN s/n, \\ Col. Playa Palo de Santa Rita, La Paz, B.C.S. 23096. México \\ ²Dto. Economía, UAB.C.S., Km 5.5. Carretera al Sur, La Paz, B.C.S. 23091. México \\ ${ }^{3}$ Departamento de Biotecnologías, Centro Interdisciplinario de Ciencias Marinas del Instituto Politécnico Nacional. Av. IPN s/n, \\ Col. Playa Palo de Santa Rita, La Paz, B.C.S. CP 23096. México \\ e-mail: dsiquei@ipn.mx
}

Siqueiros Beltrones D. A., U. Argumedo Hernández and C. Landa Cancigno. 2015. Uncommon species diversity values in epiphytic diatom assemblages of the kelp Eisenia arborea. Hidrobiológica 26 (1): 61-76.

\begin{abstract}
Macroalgae are an ideal substratum for multiple species of diatoms that are ingested along with their hosts by many species of grazers including abalones (Haliotis spp.). Much of the diet of abalones along the western coast of the Baja California peninsula (Mexico) depends on blades of the kelp Macrocystis pyrifera that is heavily colonized by diatoms. Although the kelp Eisenia arborea (its ecological alternative) is an acceptable food-source for Haliotis spp., the epiphytic diatom flora living on this kelp was hitherto unknown. Thus, the association structure of the epiphytic diatoms growing on blades of $E$. arborea from the western coast of Baja California Sur (B.C.S.) was determined. We tested the hypothesis that the epiphytic diatom assemblages on blades of $E$. arborea collected at different dates would show low species diversity and taxa representing distinct stages of succession. We identified 99 diatom taxa that represent the first floristic list of diatoms living on $E$. arborea. Values of diversity $\left(\mathrm{H}^{\prime}\right)$ were lower than usual and, together with an extremely high dominance of Pteroncola inane (a new record for the region), the structure of the diatom assemblage is regarded atypical, similar to those measured for assemblages from extreme environments. However, structure analysis did not permit distinction of succession stages in the epiphytic diatom assemblage.
\end{abstract}

Key words: Bacillariophyceae, first record, floristics, kelps, macroalgae.

\section{RESUMEN}

Las macroalgas constituyen un sustrato ideal para muchas especies de diatomeas, algunas de las cuales proliferan y son ingeridas junto con su hospedero por varias especies de herbívoros entre las que se hallan los abulones Haliotis spp. Gran parte de la alimentación de los abulones en la costa occidental de la Península de Baja California, México, depende de láminas de Macrocystis pyrifera colonizadas por diatomeas. Aunque el kelpo Eisenia arborea (su alternativa ecológica) es un alimento aceptable para Haliotis spp., hasta ahora se desconocía qué especies de diatomeas epífitas albergaba. De acuerdo con esto se determinó la estructura de las asociaciones de diatomeas epifitas de $E$. arborea de la costa oeste de B.C.S. Se contrastó la hipótesis de que las asociaciones de diatomeas epifitas de $E$. arborea, recolectadas en diferentes fechas presentarían una baja diversidad de especies, y se encontrarían diatomeas (especies) representativas de etapas de sucesión distintas. Así, se elaboró la primera lista florística representativa de diatomeas epifitas de $E$. arborea que redituó 99 taxa para la costa occidental de B.C.S. En conclusión, la estructura de la taxocenosis es considerada atípica y semeja aquellas de ambientes extremos con valores bajos de diversidad $\left(\mathrm{H}^{\prime}\right)$, destacando la dominancia extrema del taxón Pteroncola inane, el cual constituyó un nuevo registro para la región. El análisis de la estructura de las taxocenosis de diatomeas epifitas en láminas de E. arborea y sus variaciones no permitió distinguir etapas de sucesión.

Palabras clave: Bacillariophyceae, florística, kelpos, macroalgas, primer registro. 


\section{INTRODUCTION}

Macroalgae are an ideal substratum for many species of Bacillariophyceae. Over two hundred diatom taxa living as epiphytes on multispecies macroalgal assemblages have been recorded for the southern Baja California peninsula, both along the west coast (Siqueiros Beltrones and Valenzuela Romero, 2004; Siqueiros Beltrones and López-Fuerte, 2006) and the east coast (Siqueiros Beltrones and Hernández Almeida, 2006). However, a high number of diatom taxa has also been recorded living on a single species of macroalgae, such as in the giant kelp Macrocystis pyrifera L. (C. Agardh) where the number of diatom species surpassed 170 taxa for several sampling dates (Siqueiros Beltrones et al., 2002; Siqueiros Beltrones and Argumedo-Hernández, 2005; Argumedo-Hernández and Siqueiros Beltrones, 2008). Moreover, in a recent study where a single specimen of the rhodophyte Ploclamiun cartilagineum (Lamoroux) Dixon was examined, as many as 42 diatom taxa were recorded (Siqueiros Beltrones and Argumedo-Hernández, 2014a).

Multiple species of diatoms colonize macroalgal substrates and are ingested along with their hosts by many species of grazers, including abalone (Haliotis spp.). In particular, the main interest surrounding epiphytic diatoms of $M$. pyrifera comes from its role as the main foodsource for several abalone species whose diets depend strongly on its heavily epiphytized blades, which is the most abundant kelp on the western coast of the Baja California peninsula (Mexico).
Based on the above, we were interested in determining which diatom taxa were to be found living on other macroalgae that are also grazed by abalone (Siqueiros Beltrones et al., 2002); the phaeophyte Eisenia arborea Areschoug seemed as the next-best option, inasmuch as it is the second most abundant kelp along the western coast of the peninsula (Hernández-Carmona et al., 2009), and would represent an ecological alternative, particularly when the $M$. pyrifera forests disappear during El Niño events. Like M. pyrifera, E. arborea is distributed from British Columbia, Canada, down to Bahía Magdalena, Mexico, in the intertidal zone where it forms dense beds over rocky substratum (Pedroche et al., 2008). We thus assumed that the epiphytic diatom assemblage it harbored would be similar to that of $M$. pyrifera in species composition and structure, i.e., species richness, diversity, dominance. However, the first ex profeso observations made on E. arborea blades from the same region did not support such expectations because diatoms were not found (Siqueiros Beltrones et al., 2002). Nonetheless, the presence of diatoms on blades of $E$. arborea from the same region was recently noted when samples of this kelp were processed for biochemical assays (Muñoz, M., IPN-CICIMAR, com. pers.). After verifying the report, we established our objective to describe the diatom assemblages on the basis of their species composition and association structure. Thus, based on previous observations in epiphytic diatoms of M. pyryfera (Argumedo Hernández and Siqueiros Beltrones, 2008,) we tested the hypothesis that, on the blades of $E$. arborea from different

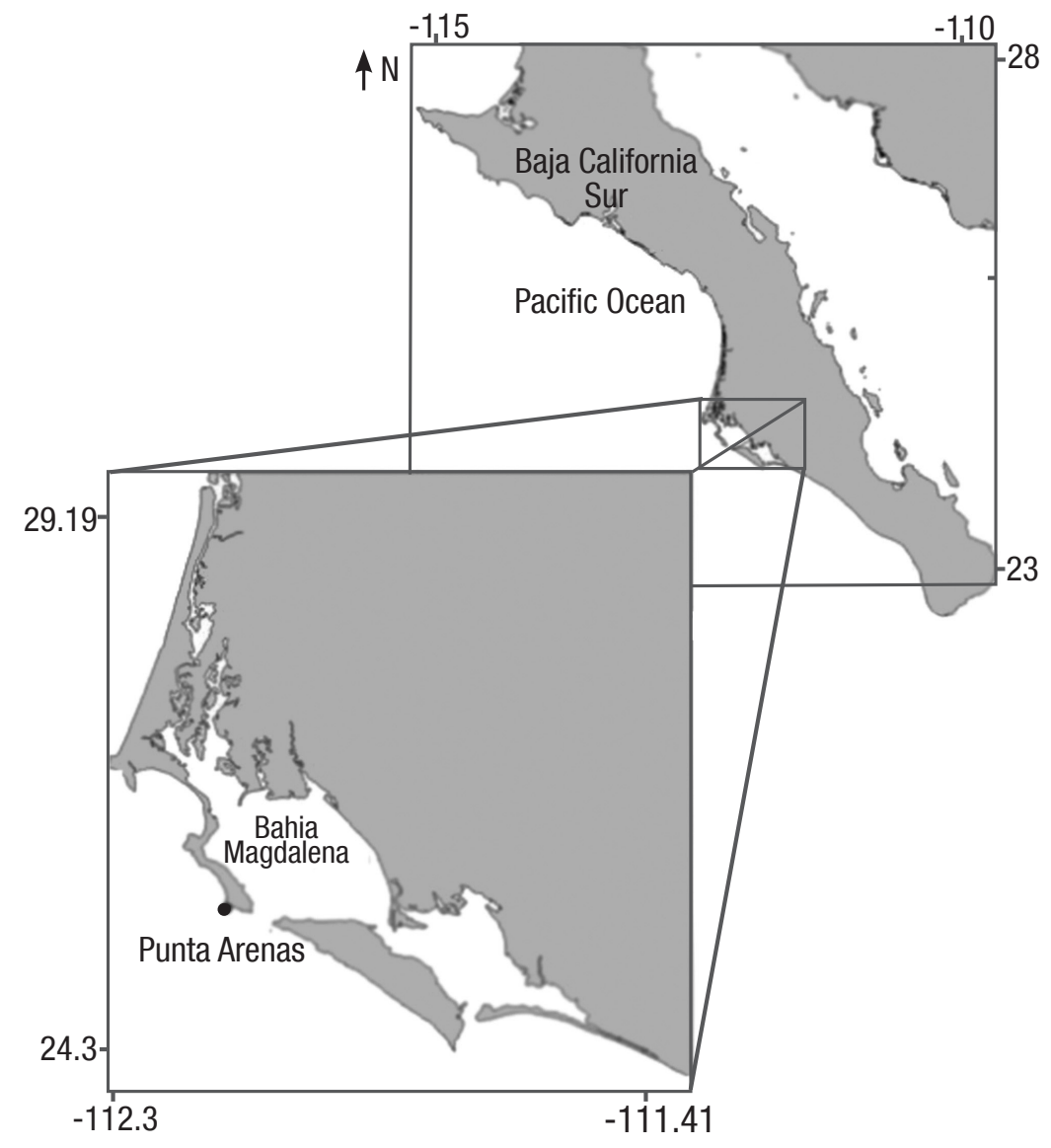

Figure 1. Location of sampling site Punta Arenas off Isla Magdalena, B.C.S., México. 
Table 1. Diatom taxa living on blades of Eisenia arborea off Isla Magdalena, B.C.S., Mexico collected from September 2013 to May $2014 .{ }^{*}$ New record for the Mexican NW region; **Record reported in Siqueiros Beltrones and Argumedo Hernández (2014b) for the same survey.

\begin{tabular}{|c|c|c|c|}
\hline TAXA & Presence & TAXA & Presence \\
\hline Achnanthes manifera Brun & rare & Grammatophora macilenta W. Smith & common \\
\hline Achnanthes yaquinensis McIntire et Reimer & rare & Grammatophora marina (Lyngbye) Kützing & common \\
\hline Actinocyclus curvatulus Janisch & common & Grammatophora marina var. subundulata Grunow & rare \\
\hline Actinoptychus aster Brun & common & Grammatophora oceánica (Ehrenberg) Grunow & common \\
\hline Actinoptychus senarius (Ehrenberg) Ehrenberg & rare & Grammatophora undulata Ehrenberg & rare \\
\hline Amphicocconeis disculoides (Ehr.) Ehrenberg & common & Hantzschia amphioxys (Ehrenberg) Grunow & rare \\
\hline Amphora angustissima Heiden in Heiden et Kolbe & less common & Hyalosynedra laevigata (Grunow) Williams et Round & common \\
\hline Amphora angusta Gregory & common & Licmophora gracilis (Ehrenberg) Grunow & rare \\
\hline Amphora cf. exilitata Giffen & common & Licmophora communis (Helberg) Grunow & rare \\
\hline Amphora holsaticoides Naguma et Kobayashi & less common & Lyrella exsul (A. Schmidt) D.G. Mann & rare \\
\hline Amphora proteus var. contigua Cleve & common & Mastogloia macdonaldii Grevillei & rare \\
\hline Anaulus cf. minutus Grunow & rare & Melosira sp. & rare \\
\hline Asteromphalus arachne (Brébisson) Ralfs & rare & Navicula cancellata Donkin & less common \\
\hline Azpeitia nodulifera (Schmidt) Fryxell et Sims & common & Navicula cf. agnita Hustedt & less common \\
\hline Berkeleya rutilans (Trentenpohl ex Roth) Grunow & abundant & Navicula cf. feuenbornii Hustedt & less common \\
\hline Biddulphia biddulphiana (Boyer) J.E Smith & rare & Navicula cf. incerta Grunow & less common \\
\hline Biddulphia grundleri A. Schmidt & rare & Navicula cf. mollissima Hustedt & rare \\
\hline Caloneis cf. linearis (Grunow) Boyer & common & Navicula clavata var. caribaea Cleve & rare \\
\hline Campyloneis grevillei (Wm. Smith) Grunow et Eulenstein & rare & Navicula directa (Smith) Ralfs & common \\
\hline Campylopyxis garkeana (Grunow) Medlin & abundant & Navicula diversistriata Hustedt & less common \\
\hline Campylodiscus cf. simulans Gregory & rare & Navicula Ionga Gregory & common \\
\hline Cocconeis contermina A. Schmidt & rare & Navicula pennata Schmidt & less common \\
\hline Cocconeis convexa Giffen & rare & Navicula sp. 1 & rare \\
\hline Cocconeis diminuta (Pantocsek) Hustedt & common & Nitzschia dissipata (Kützing) Grunow & less common \\
\hline Cocconeis dirupta var. flexella (Gregory) Janisch & common & Nitzschia distans Gregory & less common \\
\hline Cocconeis krameri Lange-Bertalot et Metzeltin & less common & Nitzschia hybrida Grunow & less common \\
\hline Cocconeis pseudodisruptoides Foged & $\begin{array}{l}\text { rare } \\
\text { rare }\end{array}$ & Nitzschia sp. 1 & rare \\
\hline Cocconeis scutellum Ehrenberg & common & Nitzschia punctata var. coarctata (Grunow) Hustedt & common \\
\hline Cocconeis speciosa Gregory & common & Nitzschia sicula (Castracane) Hustedt & common \\
\hline Cocconeis vetusta A. Schmidt & rare & Parlibellus sp. & rare \\
\hline Coscinodiscus crenulatus Grunow & rare & Paralia sulcata f. radiata Grunow & common \\
\hline Coscinodiscus radiatus Ehrenberg & common & Paralia sulcata var. crenulata Grunow & common \\
\hline Coscinodiscus rothii (Ehrenberg) Grunow & rare & Podosira stelliger (Bailey) Mann & common \\
\hline Cyclotella litoralis Lange et Syvertsen & common & Psammodiscus nitidus (Gregory) Round et Mann & common \\
\hline Delphineis surirella var. australis (Petit) Tsarenko & rare & Pteroncola inane (Giffen) Round & very abundant \\
\hline Denticula kuetzingii Grunow & rare & Raphoneis surirella var. ceylanica (Cleve) N. Foged & rare \\
\hline Diploneis aestuari Hustedt & rare & Rhoicosphenia adolphii Schmidt & common \\
\hline Diploneis bombus Ehrenberg & rare & Rhoicosphenia cf. marina (Smith) M. Schmidt & abundant \\
\hline Diploneis cf. chersonensis (Grunow) Cleve & rare & Rhoicosphenia genuflexa (Kützing) Medlin & abundant \\
\hline Diploneis crabro Ehrenberg & rare & Roperia tesselata (Roper) Grunow & common \\
\hline Diploneis didyma (Ehrenberg) Cleve & rare & Seminavis ventricosa (W.Gregory) M. García-Baptista & common \\
\hline Diploneis litoralis (Donkin) Cleve & less common & Staurophora sp. & common \\
\hline Diploneis obliqua (Brun) Hustedt & rare & Tabularia barbatula (Kützing) D.M. Williams et Round & rare \\
\hline Diploneis papula (A. Schmidt) Cleve & common & Tabularia investiens (W. Smith) Williams et Round & common \\
\hline Diploneis papula var. constricta Hustedt & rare & Tabularia tabulata var. fasciculata (Kütz.) Williams et Round & rare \\
\hline Diploneis smithii (Brébisson) Cleve & rare & Thalassiosira eccentrica (Ehrenberg) Cleve & common \\
\hline Gomphonemopsis pseudexigua (Simonsen) Medlin & common & Thalassiosira sp. & common \\
\hline Gomphoseptatum aestuarii (Cleve) Medlin & abundant & Trachyneis aspera Ehrenberg & common \\
\hline Grammatophora hamulifera Kützing & abundant & Trachyneis velata Schmidt & common \\
\hline
\end{tabular}




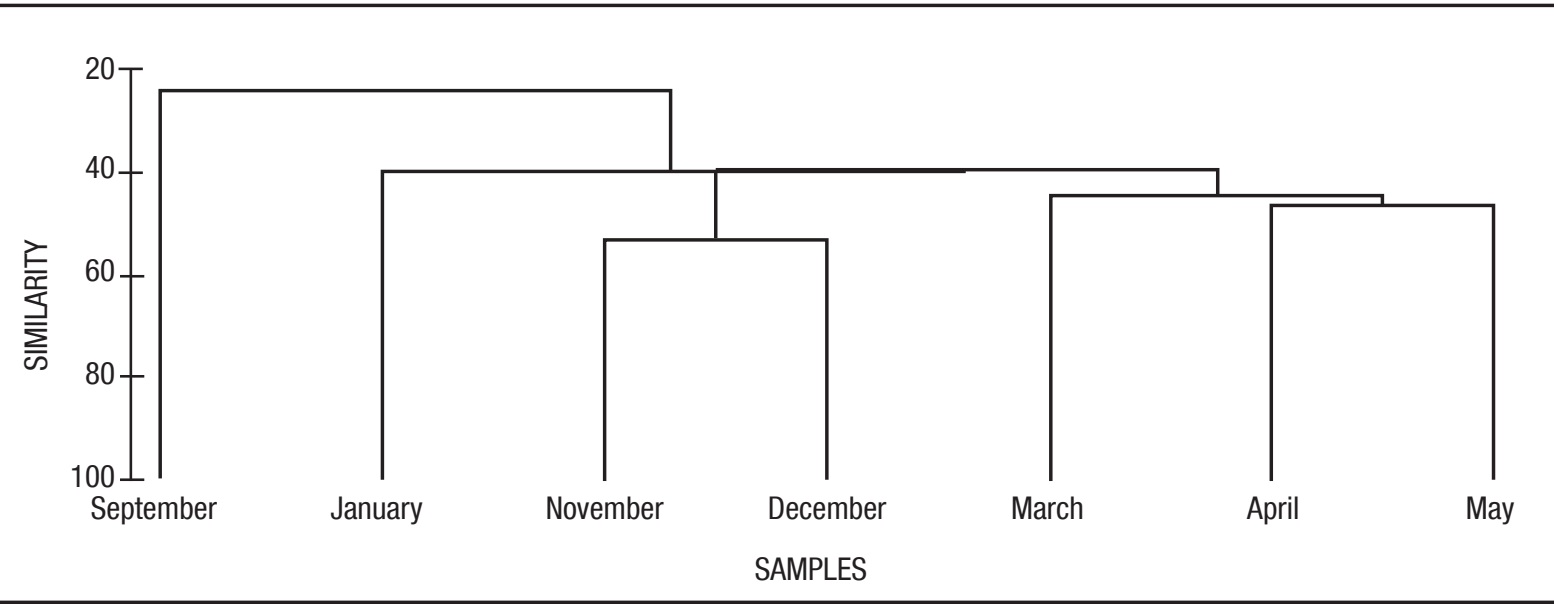

Figure 2. Similarity between samples of epiphytic diatom assemblages living on blades of Eisenia arborea from B.C.S., measured with the Jaccard index.

dates, diatom taxa representing distinct stages of succession would be found together with either abundant pioneer taxa such as Cocconeis spp., or naviculoid opportunistic species that depict advanced stages of colonization, in both cases associated with low values of diversity. We conclude that the structure of the diatom assemblage is unusual, similar to those of assemblages from extreme environments. However, structure analysis did not permit the distinction of succession stages in the epiphytic diatom assemblage.

\section{MATERIALS AND METHODS}

Blades of E. arborea were collected at Punta Arenas $\left(24^{\circ} 33^{\prime} 2^{\prime \prime} \mathrm{N}\right.$ and $112^{\circ} 05^{\prime} 28^{\prime \prime}$ W), off Isla Magdalena (Fig. 1), in the west coast of B.C.S. Samplings were gathered in September, November, and December, 2013, and in January, March, and May, 2014, at a depth of 5-10 m by scuba diving. The blades were dried before being transported to the laboratory, where the most noticeable epiphytized blades were selected among those having few or no bryozoans. Epiphytes on the surface of the $E$. arborea blades from each date were scraped off using a glass slide while rinsing with purified water into a dissecting tray. The resul- ting epiphyte concentrate was stored in assay tubes; decanted water was eliminated and then a sample of each concentrate was oxidized in assay tubes using a mixture of commercial ethanol and nitric acid at a ratio of 1:3:5 that varied depending on the amount of organic matter in each sample (Siqueiros-Beltrones, 2002). Afterwards, repeated rinsing was done using purified water until a $\mathrm{pH} \geq 6$ was reached. From each cleaned diatom sample five (double) permanent preparations and a repetition were mounted using the synthetic resin Pleurax $(R l=1.7)$.

Diatom taxa were identified under a phase contrast compound microscope with planapo-chromatic lenses at $1000 \times$, following the references of Cleve-Euler (1968); Desikachary (1988); Hendey (1964); Hustedt (1959; 1961-66); López-Fuerte et al. (2010); Peragallo and Peragallo (1908); Round et al. (1990); Schmidt et al. (1874-1959); Siqueiros Beltrones (2002); Siqueiros Beltrones and Valenzuela-Romero (2001); Siqueiros Beltrones et al. (2004); Siqueiros Beltrones and Hernández-Almeida (2006); Witkowski et al. (2000). A representative micro-photographic record of the diatom taxa is provided.

In order to describe the structure of the epiphytic diatom assemblages of $E$. arborea, the relative abundances of the taxa were estimated

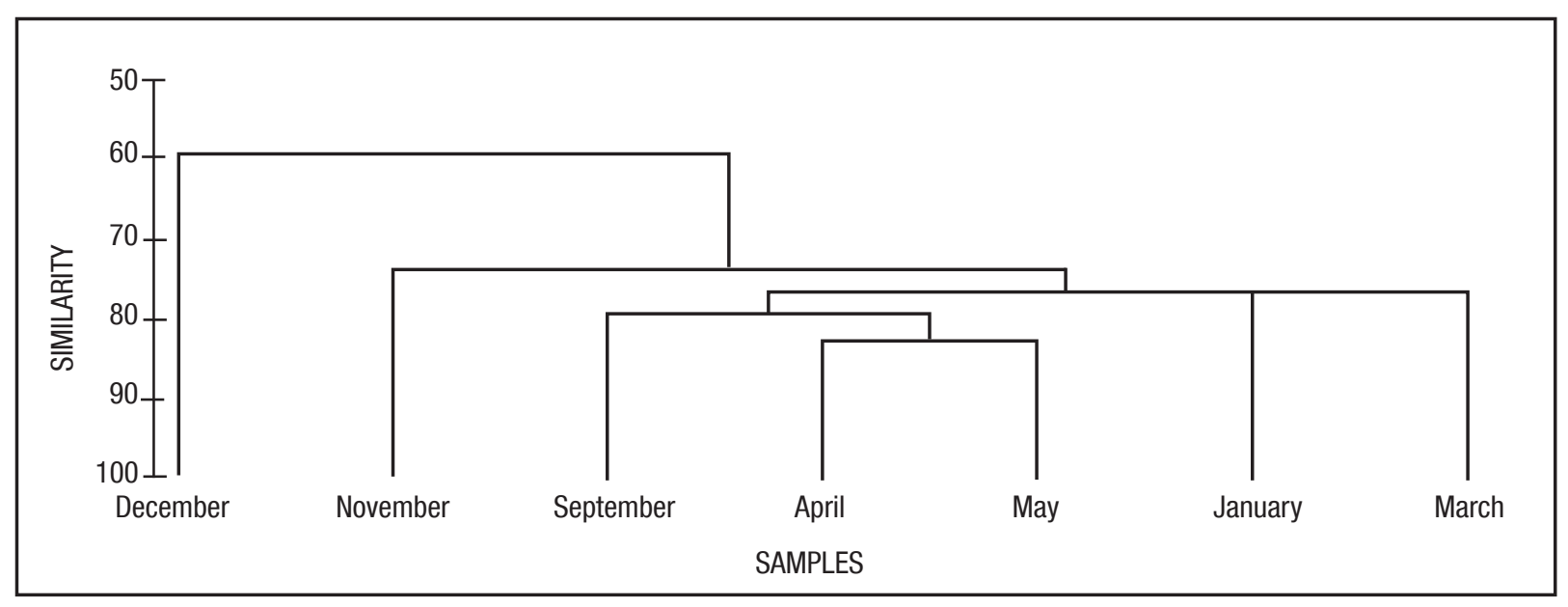

Figure 3. Similarity between samples of epiphytic diatom assemblages living on blades of Eisenia arborea in B.C.S., measured with the Bray-Curtis index. 
Table 2. Relative abundance of the main diatom taxa in the epiphytic assemblages living on blades of Eisenia arborea collected in B.C.S.., Mexico from September 2013 to May 2014.

\begin{tabular}{ll}
\hline \multicolumn{1}{c}{ TAXA } & $\%$ \\
\hline Pteroncola inane & 66.37 \\
Campylopyxis garkeana & 4.89 \\
Anaulus cf. minutus & 3.67 \\
Rhoicosphenia adolphii & 3.08 \\
Berkeleya rutilans & 2.86 \\
Gomphoseptatum aestuarii & 2.61 \\
Gomphonemopsis pseudexigua & 2.42 \\
Amphicocconeis disculoides & 1.97 \\
Tabularia investiens & 1.72 \\
Gramatophora marina & 1.47 \\
Navicula incerta & 1.42 \\
\hline Cumulative relative abundance & 92.47
\end{tabular}

based on an approximate sample size (n) of 500 valves (Siqueiros Beltrones, 2002) per sample $(\mathrm{N}=3600)$. With these, the following indices for estimating diversity were calculated: Shannon's $\left(H^{\prime}\right)$, Pielou's $\left(J^{\prime}\right)$, Simpson's $(\lambda)$; and the Bray-Curtis index for measuring similarity between samples, which was complemented using the Jaccard index. All computations were done using program Primer 6 v 6.1.6.

\section{RESULTS}

Floristics. The resulting floristic list shows a total of 99 diatom taxa living on blades of $E$. arborea (Table 1). A photographic catalogue including most of the taxa is provided (Figs. 4-158). Most taxa, either common or rare, are epiphytic forms, except for certain taxa like the Lyrella forms and Diploneis spp. that are epipelic. Others, such as the centric forms Biddulphia biddulphiana (Boyer) J.E. Smith, Paralia sulcata f. radiata Grunow, Paralia sulcata var. crenulata Grunow, and Podosira stelliger (Bailey) Mann are typical epiphytes of the region; biraphids forms such as Campylopyxis garkeana (Grunow) Medlin, Gomphonemopsis pseudexigua (Simonsen) Medlin, Gomphoseptatum aestuarii (Cleve) Medlin, and Rhoicosphenia genuflexa (Kützing) Medlin are characteristic epiphytes of $M$. pyrifera and were proportionally re-

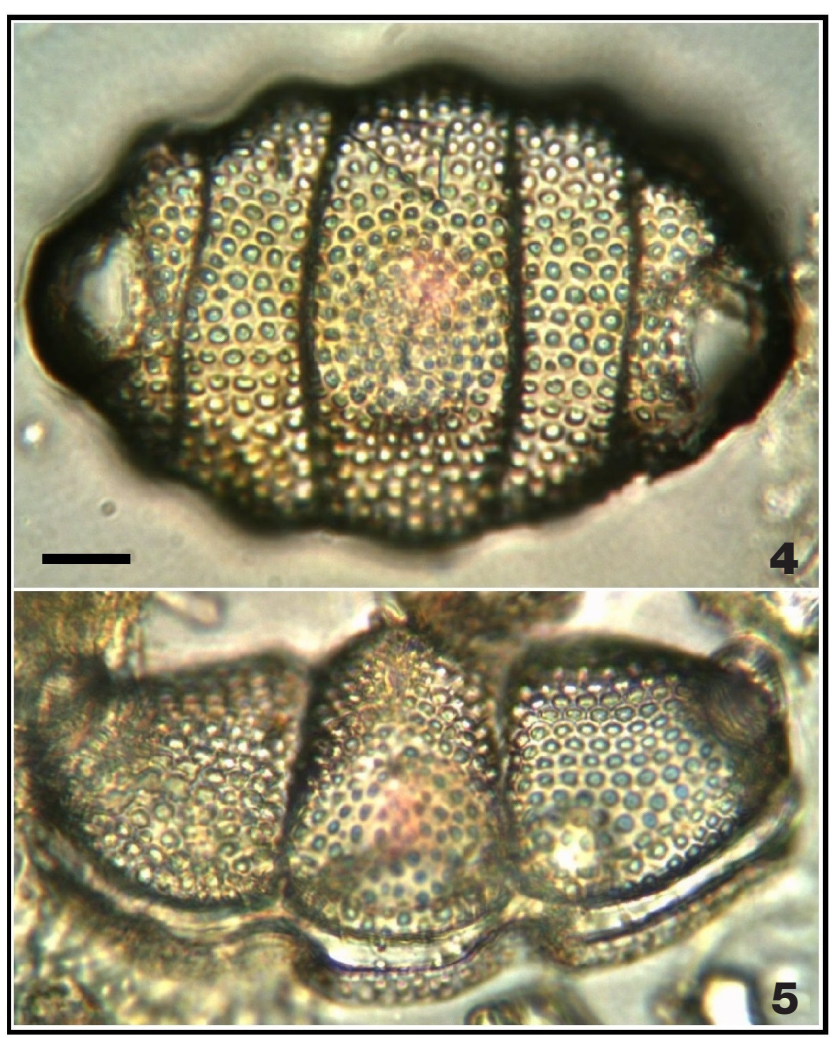

Figures 4-5. 4) Biddulphia biddulphiana; 5) Biddulphia grundleri. Scale bar = $10 \mu \mathrm{m}$ for both specimens.

presented; however, others such as Grammatophora spp., which are common epiphytes were not as conspicuous as in other macroalgae of the region. On the other hand, the araphid Pteroncola inane (Giffen) Round (Siqueiros Beltrones and Argumedo Hernández, 2014b) and the centric Biddulphia grundleri A. Schmidt constitute new records for the Mexican NW region. The former was extremely abundant in most samples, while the latter was rare.

As implied above, the epiphytic diatom assemblage on $E$. arborea was characterized by the extreme dominance by a single taxon, $P$. inane (Figs. 50, 52-55), which represented between $33 \%$ and $94 \%$ of the

Table 3. Diversity values estimated for the epiphytic diatom assemblages found on blades of Eisenia arborea in Isla Magdalena, B.C.S. from September 2013 to May 2014. S= species richness; $N=$ valves counted; J'= equitability; $H^{\prime}=$ Shannon's diversity; $\lambda=$ Simpson's dominance; $1-\lambda=$ Simpson's diversity.

\begin{tabular}{llllllll}
\hline FECHA & $\mathrm{S}$ & $\mathrm{N}$ & $\mathrm{J}^{\prime}$ & $\mathrm{H}^{\prime}$ & $\lambda$ & $1-\lambda$ & Valve abundance \\
\hline September & 6 & 478 & 0.12 & 0.30 & 0.93 & 0.07 & very abundant \\
November & 24 & 497 & 0.53 & 2.42 & 0.38 & 0.62 & scarce \\
December & 28 & 505 & 0.61 & 2.93 & 0.21 & 0.79 & scarce \\
January & 15 & 582 & 0.47 & 1.83 & 0.47 & 0.53 & less abundant \\
March & 24 & 530 & 0.53 & 2.43 & 0.38 & 0.62 & scarce \\
April & 22 & 557 & 0.41 & 1.84 & 0.49 & 0.51 & scarce \\
May & 25 & 452 & 0.31 & 1.44 & 0.64 & 0.36 & very scarce \\
\hline
\end{tabular}




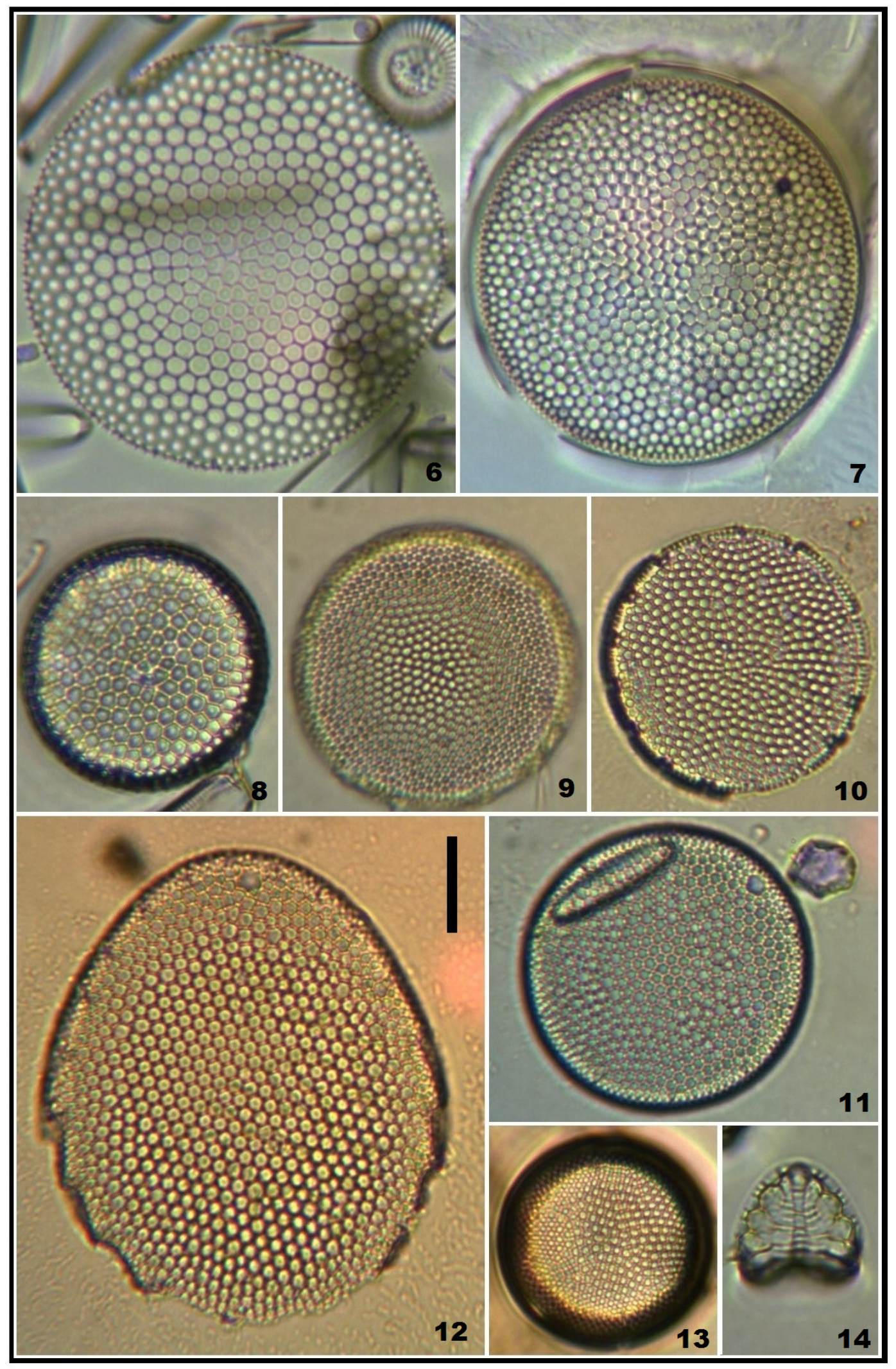

Figures 6-14. 6, 9) Coscinodiscus radiatus; 7) Coscinodiscus rothii; 8) Azpeitia nodulifer; 10) Coscinodiscus crenulatus; 11-12) Roperia tesselata; 13) Thalassiosira eccentrica; 14) Campylodiscus cf. simulans. Scale bar $=10 \mu \mathrm{m}$ for all specimens. 


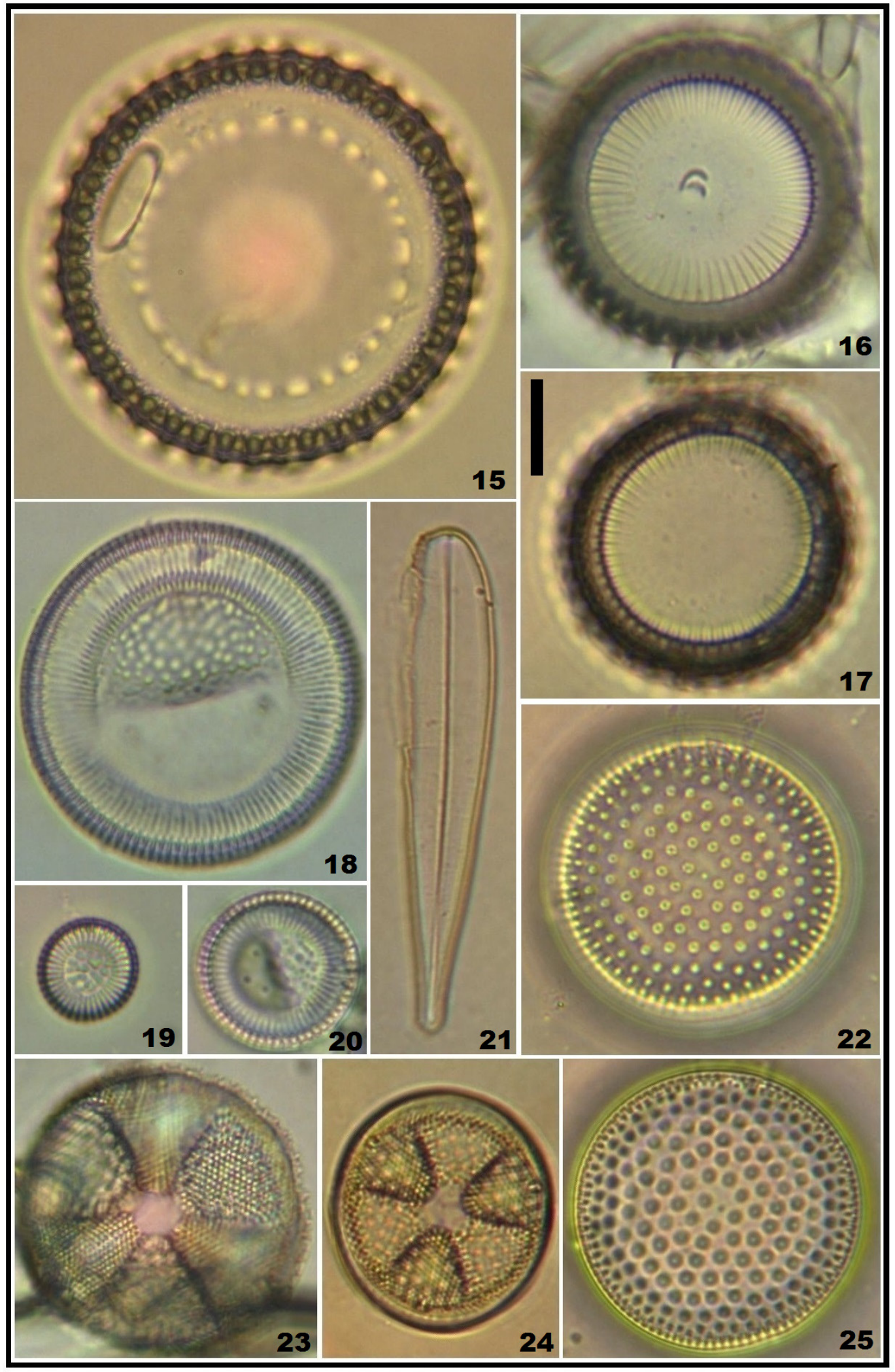

Figures 15-25. 15) Paralia sulcata var. crenulata; 16-17) Paralia sulcata f. radiata; 18-20) Cyclotella litoralis; 21) Licmophora gracilis; 22, 25) Psammodiscus nitidus; 23) Actinoptychus aster; 24) Actinoptychus senarius. Scale bar $=10 \mu \mathrm{m}$ for all specimens. 


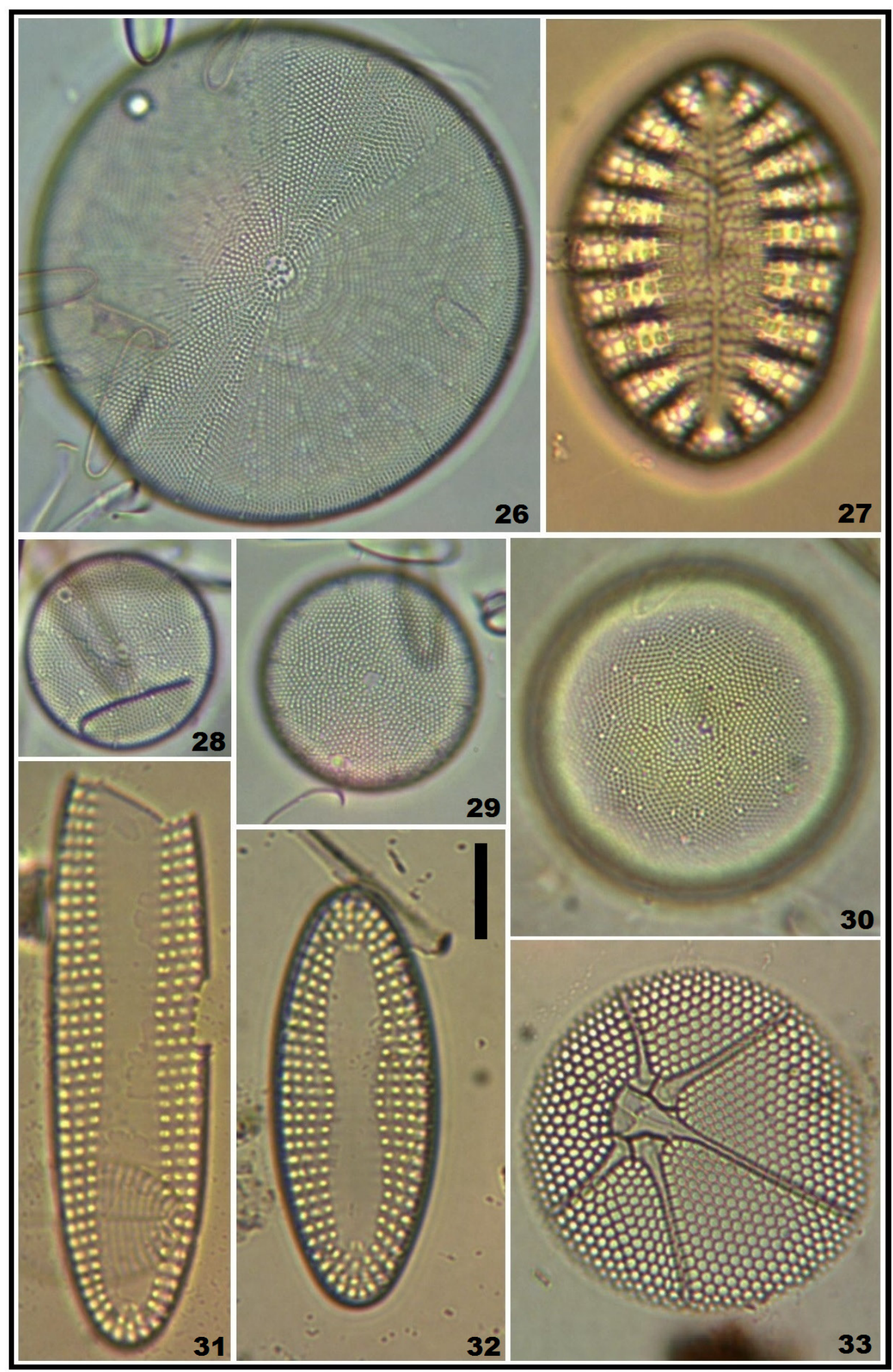

Figures 26-33. 26, 28-30) Actinocyclus curvatulus; 27) Campyloneis grevillei; 31) Raphoneis surirella var. ceylanica; 32) Delphineis surirella var. australis; 33) Asteromphalus arachne. Scale bar $=10 \mu \mathrm{m}$ for all specimens. 


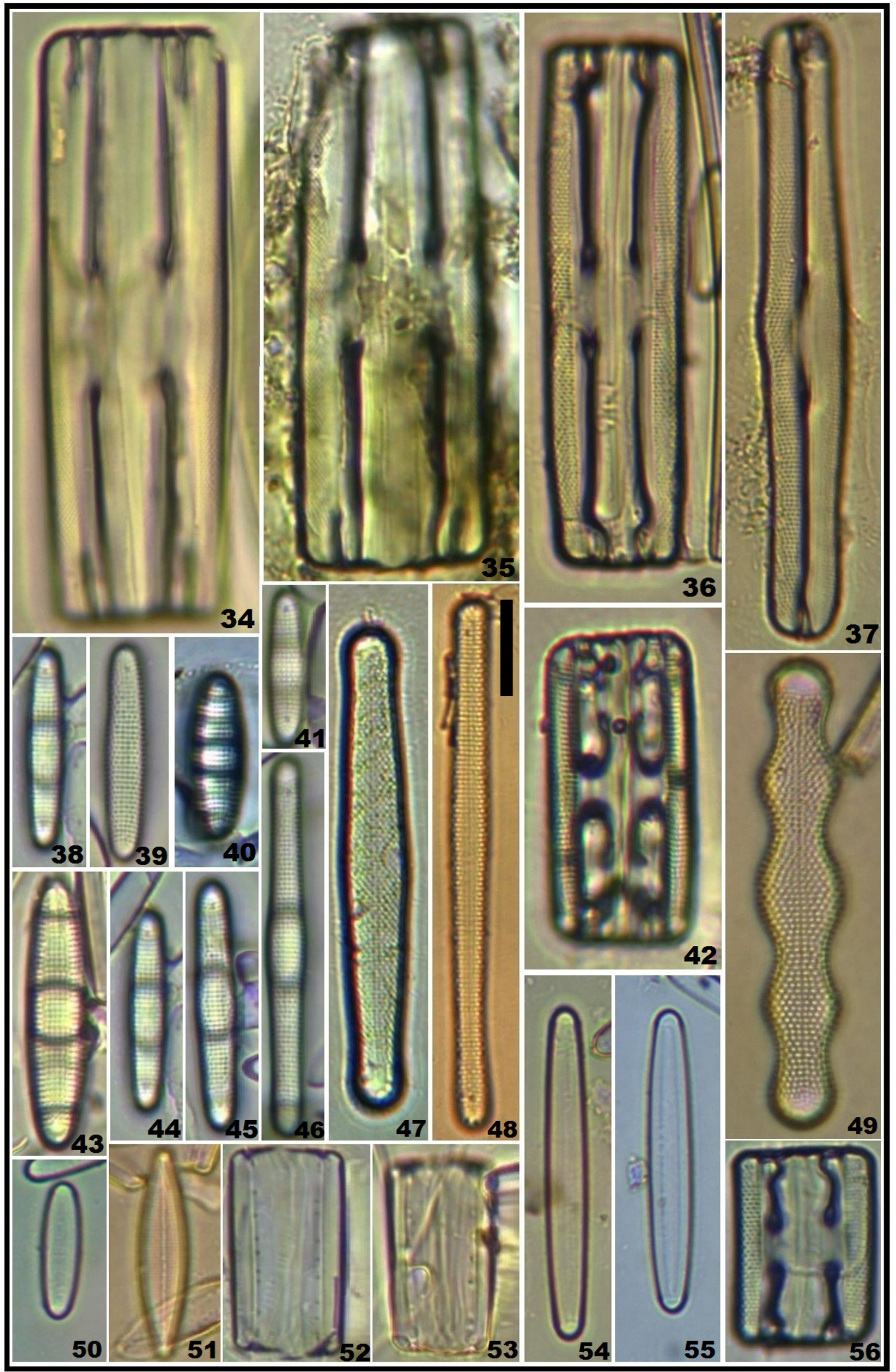

Figures 34-56. 34-35) Grammatophora macilenta; 36-37, 48) Grammatophora oceanica; 38-39, 41, 44-46, 56) Grammatophora marina; 40, 42-43) Grammatophora hamulifera; 47) Grammatophora marina var. subundulata; 49) Grammatophora undulata; 50, 52-55) Pteroncola sp.; 51) Synedra barbatula. Scale bar = $10 \mu \mathrm{m}$ for all specimens. 


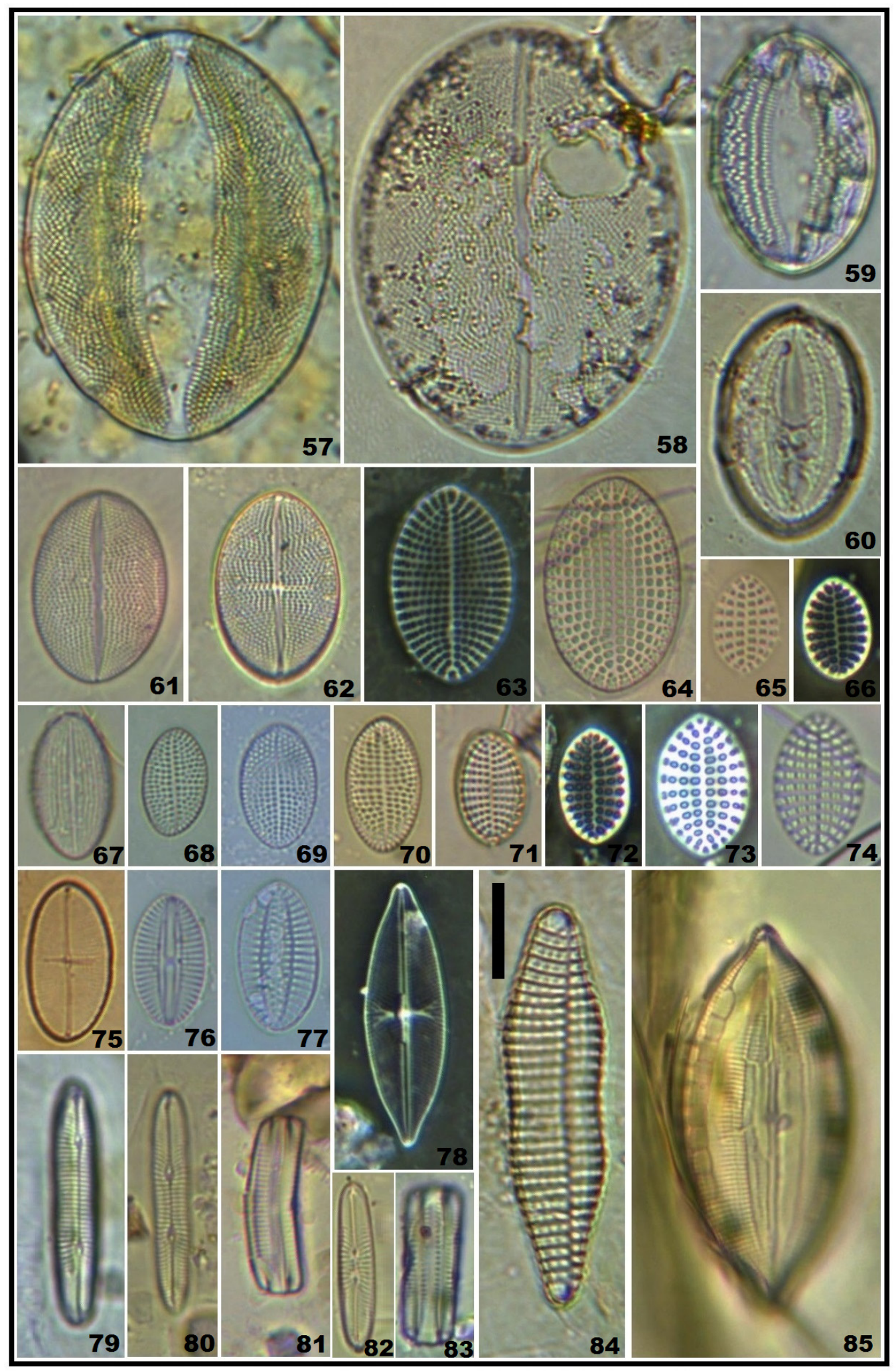

Figures 57-85. 57) Cocconeis vetusta; 58, 59-62, 75) Cocconeis dirupta var. flexella; 59) Cocconeis contermina; 60) Cocconeis krameri; 63-64) Cocconeis scutellum; 65, 74) Amphicocconeis disculoides; 67) Cocconeis convexa; 68-70) Cocconeis pseudodiruptoides; 69) Cocconeis diminuta; 66, 72-73) Cocconeis speciosa; 76) Diploneis aestuari; 77) Cocconeis latecostata; 78) Achnanthes manifera; 79-80) Berkeleya rutilans; 81-83) Rhoicosphenia genuflexa; 84) Achnanthes yaquinensis; 85) Mastogloia macdonaldii. Scale bar $=10 \mu \mathrm{m}$ for all specimens. 


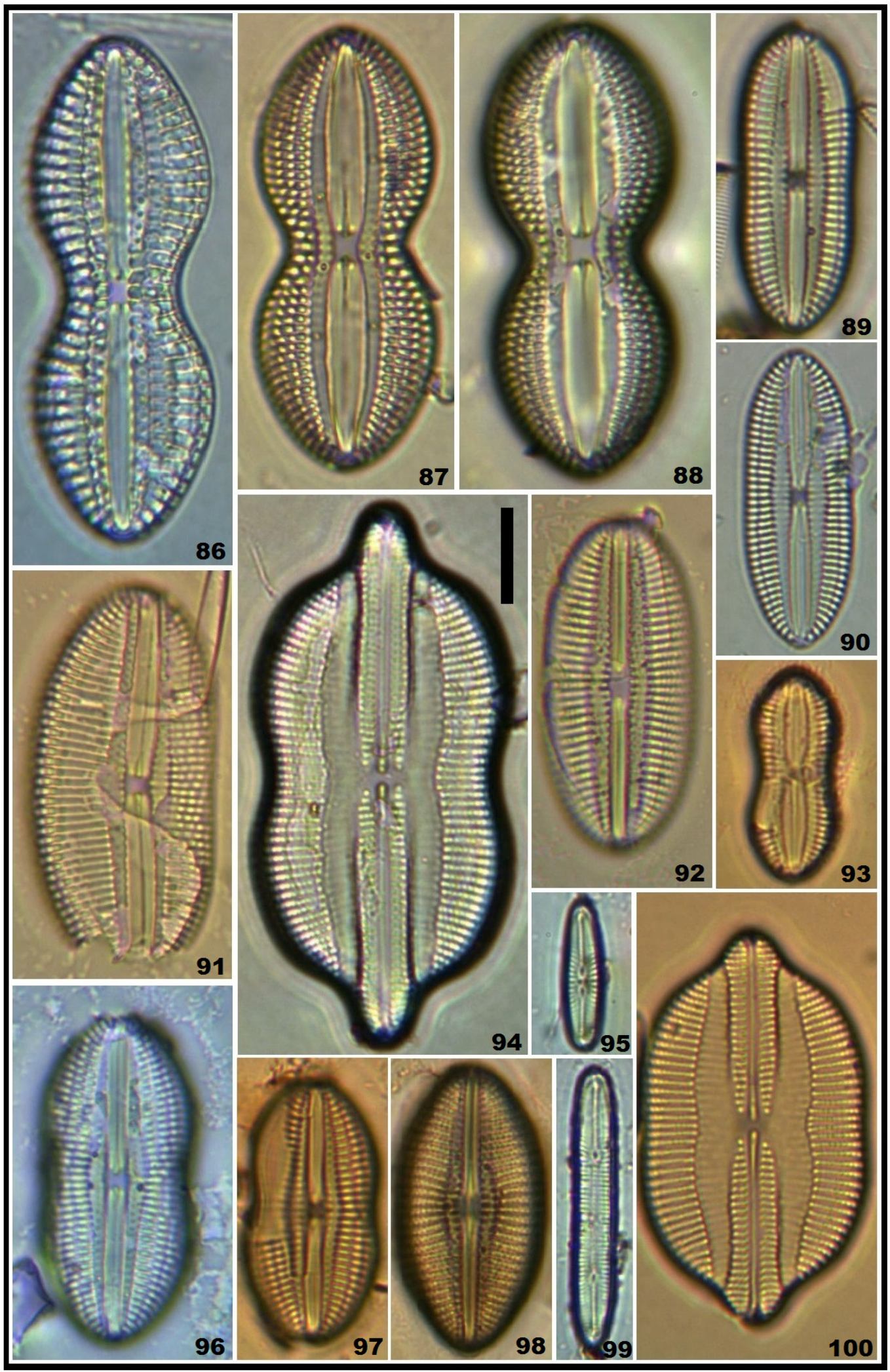

Figures 86-100. 86) Diploneis crabro; 87-88) Diploneis bombus; 89-90) Diploneis papula; 91) Diploneis obliqua; 92) Diploneis litoralis; 93) Diploneis papula var. constricta; 94) Lyrella exsul; 95) Rhoicosphenia genuflexa; 96-97) Diploneis didyma; 98) Diploneis smithii; 99) Berkeleya rutilans; 100) Navicula clavata var. caribaea. Scale bar $=10 \mu \mathrm{m}$ for all specimens. 


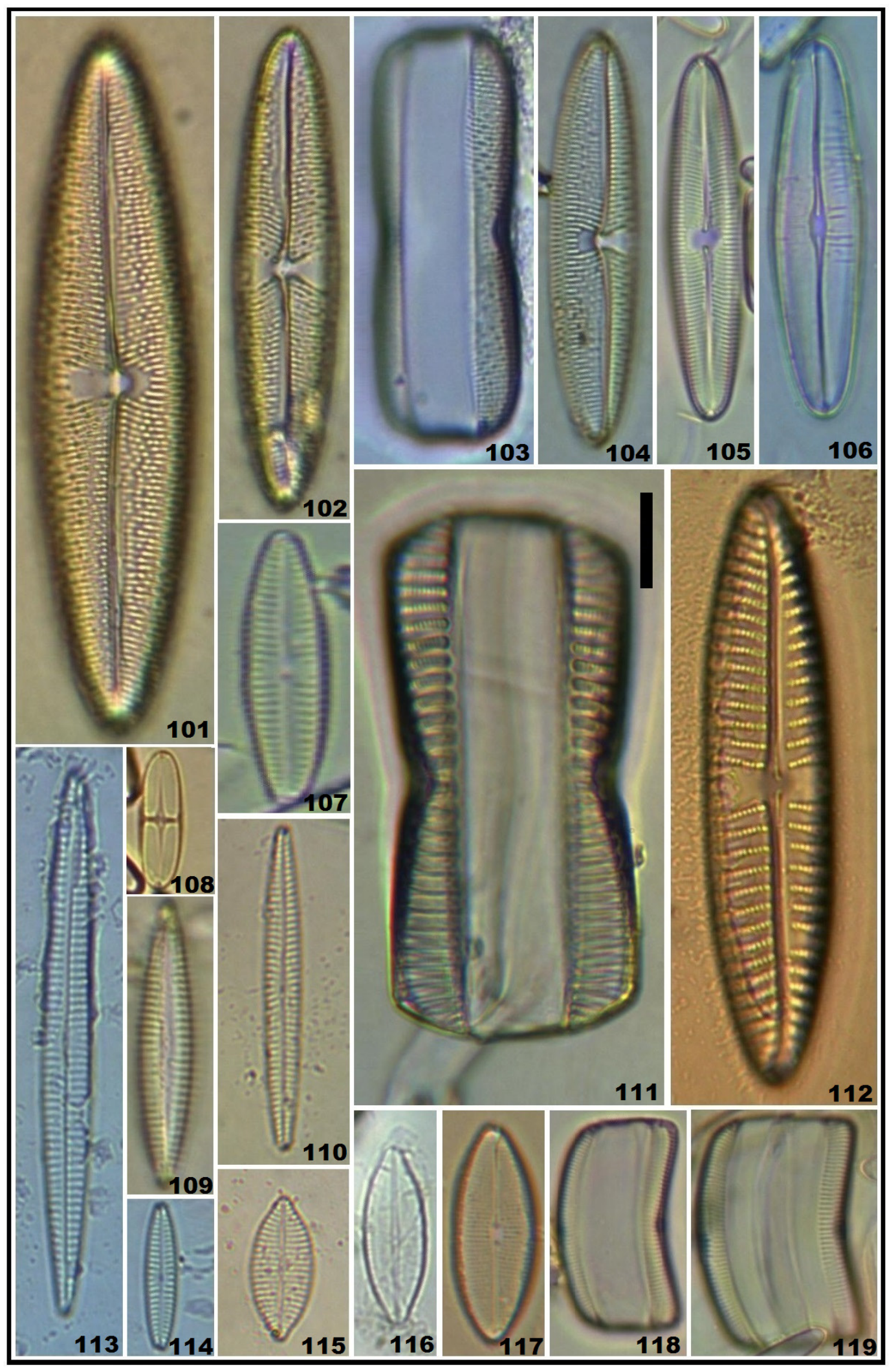

Figures 101-119. 101, 103) Trachyneis velata; 102, 104) Trachyneis aspera; 105) Campylopyxis garkeana; 106) Navicula cf. mollissima; 107) Navicula incerta; 108 Staurophora sp.; 109) Navicula cf. feuenbornii; 110, 114) Navicula cincta; 111) Navicula cancellata; 112) Navicula pennata; 113) Navicula directa; 115) Navicula diversistriata; 116) Navicula sp. 1; 117) Parlibellus sp.; 118-119) Campylopyxis garkeana. Scale bar $=10 \mu \mathrm{m}$ for all specimens. 


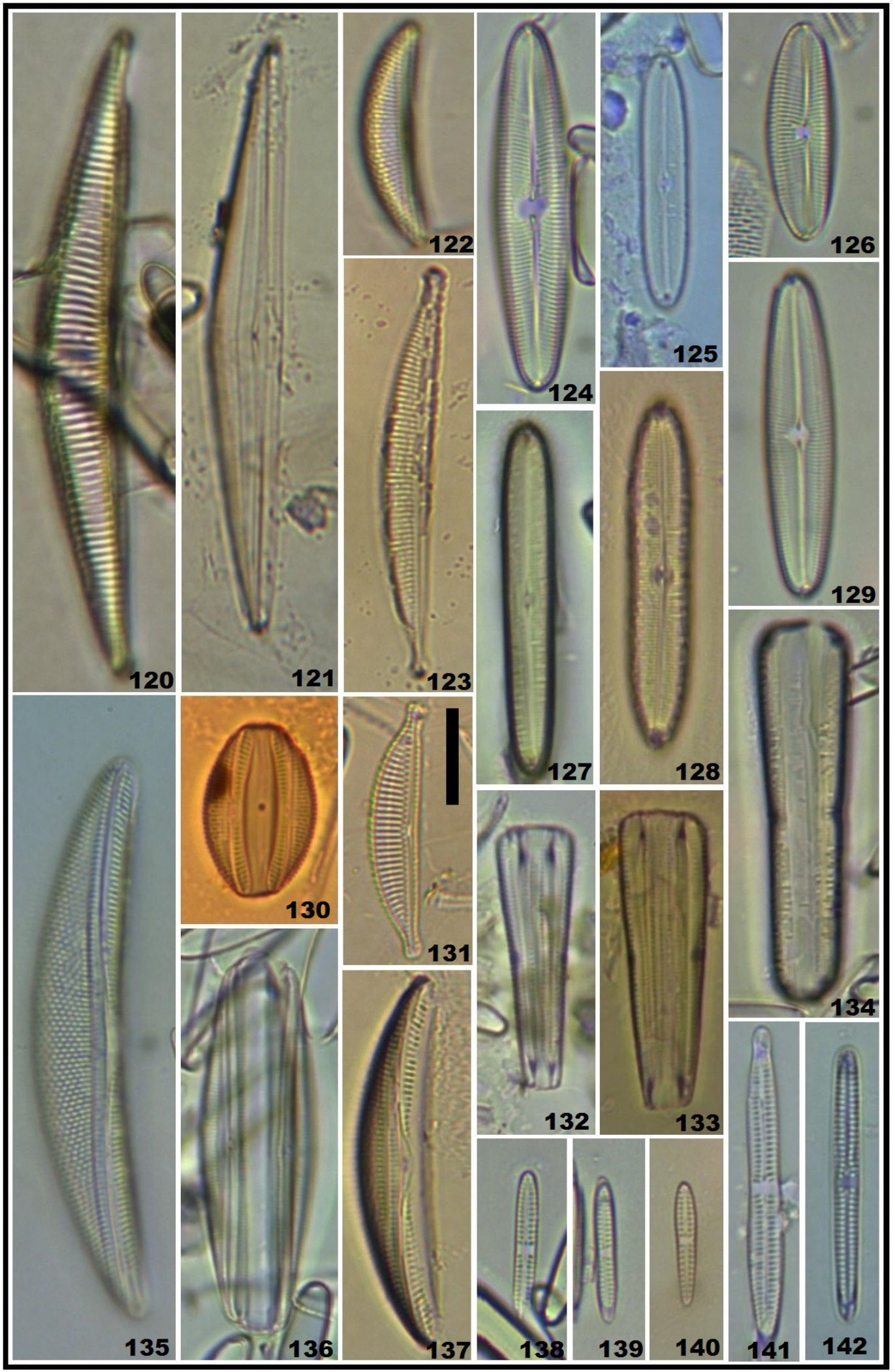

Figures 120-142. 120) Seminavis ventricosa; 121) Amphora angusta; 122, 130, 135, 137) Amphora proteus var. contigua; 123) Amphora angustissima; 124, 126, 129) Campylopyxis garkeana; 125, 127-128, 134) Caloneis linearis; 131) Amphora holsaticoides; 132-133, 141-142) Gomphoseptatum aestuarii; 138-140) Gomphonemopsis pseudexigua. Scale bar $=10 \mu \mathrm{m}$ for all specimens. 


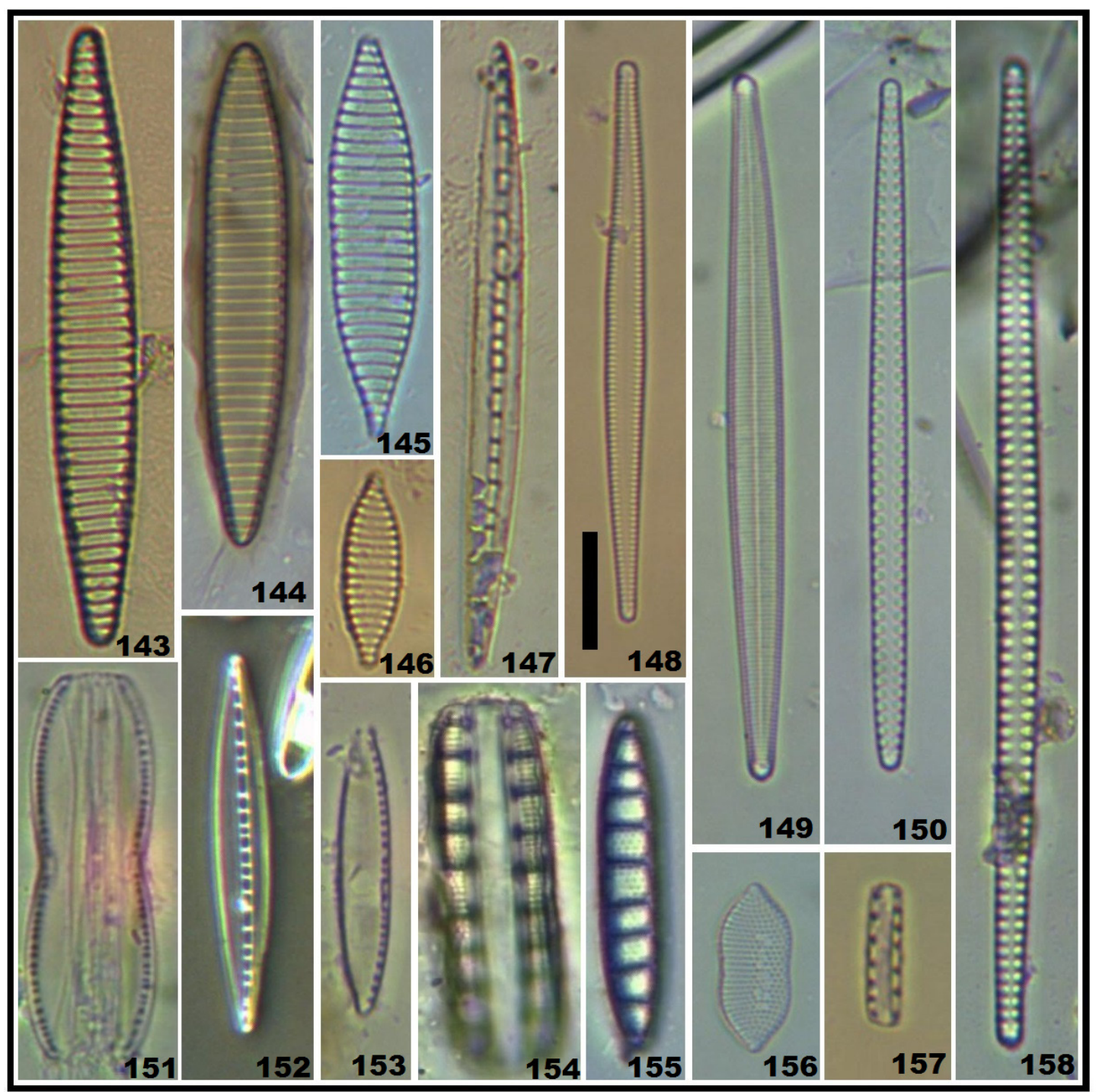

Figures 143-158. 143-146) Nitzschia sicula; 147, 152) Nitzschia distans; 148) Tabularia tabulata var. fasciculata; 149) Hyalosynedra laevigata; 150, 158) Tabularia investiens; 151) Nitzschia hybrida; 153) Nitzschia sp. 1; 154-155) Denticula kuetzingii; 156) Nitzschia punctata var. coarctata; 157) Anaulus cf. minutus. Scale bar $=10 \mu \mathrm{m}$ for all specimens.

counted valves in the different dates, and more than $66 \%$ overall ( $\mathrm{N}=$ 3600); by contrast, the second abundant taxon, Campylopyxis garkeana (Figs. 105, 118, 119) represented less than $5 \%$ of the total valves (Table 2). Moreover, the quantitative phase yielded only 54 species, most of the taxa being rare or uncommon (Table 1). In spite of the above, according to the estimated relative abundances, the described diatom assemblage exhibits a typical pattern, i.e., many rare and uncommon species, and few abundant (or very common) ones. In this case, however, it is unusual that a single species contributes $66 \%$ of the total abundance.

Species diversity. The estimated values of species diversity ranged in general from low to very low (Table 3), with the lowest value corresponding to the September sample $\left(\mathrm{H}^{\prime}=0.3 ; \mathrm{S}=6\right)$, in which Pteroncola inane was more abundant. However, in other samples where the cell concentration in the preparations was either abundant (January) or very low (April, May), due to $P$. inane, diversity values were also very low; unlike the diversity values of the samples from November, December, and March (Table 3), which are similar to those from normal (favorable) environments, as a result of their species richness $(S=24,28,24$, respectively) and equitability $\left(\mathrm{J}^{\prime}\right)$ higher than 0.5 , which are in fact atypically lower.

Similarity. The similarity values between samples of epiphytic diatom assemblages living on blades of Eisenia arborea based on presence/ absence of species (Jaccard's index) show that September is the most distinct sample $(<20 \%)$, mainly because of the absence of taxa ( $\mathrm{S}=$ 6). The rest show a similarity of around $40 \%$ which, according to other studies and the characteristics of the index, is only slightly low (Fig. 2). In contrast, when also considering the relative abundance of each taxon (Bray-Curtis index), the minimum similarity was $60 \%$ (Fig. 3), but was 
generally high (approximate 80\%), mainly due to the abundance of $P$. inane in most of the samples; the segregation of the December sample, however, has to do with an increase in the abundance of $C$. garkeana (Table 2).

The main components in the low values of diversity were thus the high abundance of $P$. inane, the scarcity of the other taxa (low S), and the low equitability. These parameters did vary between the samples (dates) but were in general atypical of benthic diatom assemblages; such low values resemble those that characterize diatom assemblages from extreme environments. According to these data, our hypothesis that diatom taxa from different dates representing distinct stages of succession would be found on the blades of $E$. arborea, together with abundant pioneer taxa or species from advanced stages of colonization, was not supported, although low values of diversity were observed. We conclude that the structure of the diatom assemblage is atypical, similar to those of assemblages from extreme environments, because of the uncommon (very) low diversity values $\left(\mathrm{S}, \mathrm{H}^{\prime}, \mathrm{J}^{\prime}\right)$. However, structure analysis did not permit the distinction of succession stages in the epiphytic diatom assemblage.

\section{DISCUSSION}

Although macroalgae are considered an ideal substratum for many species of diatoms and recent studies in NW Mexico have proven this to be so, in this case the brown alga $E$. arborea represents a good substratum only for a few diatom taxa, particularly $P$. inane, but not for most of the recorded taxa in this study. The scarcity of diatom cells and low species richness, along with the pioneer observation showing no diatoms on $E$. arborea blades (Siqueiros Beltrones et al., 2002) suggest a sui generis substratum whose study requires at least high-frequency observations. The iconographic catalog in this report may prove to be a useful reference when undertaking future studies on the epiphytic diatoms of $E$. arborea, inasmuch as the frequency of the diatom taxa and their time variation can be monitored in order to infer changes in the epiphytic diatom assemblages.

The observed species richness was approximately half of what has been recorded in similar floristic studies for either a single or for multiple macroalgae species (Siqueiros Beltrones, 2002; Siqueiros Beltrones and Hernández Almeida, 2006; Argumedo Hernández and Siqueiros Beltrones, 2008). In contrast, the floristic study mentioned earlier of a single specimen of $P$. cartilagineum showed it to be heavily epiphytized by many of the 42 taxa recorded, and coupled to a much higher value of diversity $\left(H^{\prime}=3.52\right)$, a low dominance and a high equitability, indicating that the environment provided by the host is very favorable (Siqueiros Beltrones and Argumedo Hernández, 2014a). Meanwhile, the low values of diversity observed for the diatom assemblages on $E$. arborea blades resemble those observed in diatom assemblages from extreme environments (Siqueiros Beltrones, 2002). The subtidal habitat is characterized by high energy which causes very dynamic movement of the E. arborea thalli, affecting the settlement of diatoms on the violently moving blades. Colonization is expected to be higher during periods of calm waters.

Because similarity values were high in subsamples from a same sample (Siqueiros Beltrones and Argumedo-Hernández, 2014a), they represent the same structure and ensure that the subsamples did not differ from the overall epiphytic assemblage. This suggests that the examined samples represent but one assemblage that does not show important temporal variations on the basis of species composition and association structure strongly influenced by Pteroncola inane. Accordingly, the abundance of $P$. inane determines the basic structure of the assemblage.

It is thus strange that, in spite of being so abundant, $P$. inane set a new record for the region during this investigation (Siqueiros Beltrones and Argumedo Hernández, 2014b). Such monospecific proliferations have been observed on blades of M. pyrifera e.g., Cocconeis costata var. pacifica (Grunow) Grunow (Siqueiros Beltrones et al., 2002) and Rhoicosphenia genuflexa (Kützing) Medlin (Argumedo Hernández and Siqueiros Beltrones, 2008); in these cases, however, the monospecific dominance has not been that extreme.

Based on the above, an expected succession of the taxa in the assemblage could not be observed because, although the abundance of $P$. inane was highest in the September sample, in the other dates most taxa also remained rare or uncommon. That is, the abundance of cells depended heavily on the proliferation of $P$. inane. Given the objective of this study, this property (abundance) was not quantified, but it may be inferred from the valve concentration in the examined permanent mounts (Table 2).

As noted above, the initial reported absence of diatoms on $E$. arborea (Siqueiros Beltrones et al., 2002), and the scarcity of most diatom taxa in the present study merely suggests that distinct stages of succession occur on the $E$. arborea blades as proposed in our hypothesis, but it precludes its confirmation. It is tempting to suggest that the abundance of Pteroncola inane in the examined samples represents the proliferation of a pioneer species that conditions the blade surface of $E$. arborea for other taxa, serving as an alternate substrate to $E$. arborea which could be hostile to the other diatoms. Epiphytism between diatoms is a common phenomenon (Round et al., 1990), and has been documented for this region in epiphytic diatom assemblages of M. pyrifera (Siqueiros Beltrones et al., 2002) and of $P$. cartilagineum (Siqueiros Beltrones and Argumedo Hernández, 2014a). To contrast this new hypothesis, an ex profeso design is required, including a higher frequency sampling species, i.e., several samplings within a single season to contrast said hypothesis, which may also prove useful in monitoring other diatoms.

From a pragmatic point of view, in spite of the low species diversity of epiphytic diatoms observed on blades of $E$. arborea, the sole proliferation of Pteroncola inane combined with many rare or uncommon taxa are expected to enrich the kelp's nutritional value which would favor various species of grazers including those of economic importance like abalones (Haliotis spp.). In fact, much of the interest in the study of $M$. pyrifera focuses on its role as food for abalone. As with other macroalgae, epiphytic diatoms are considered to be enriching their food value (Siqueiros Beltrones and Argumedo Hernández, 2005; Siqueiros Beltrones and Argumedo Hernández, 2014a), inasmuch as many epiphytic diatoms have been observed within the gut contents of juveniles and adults of abalone collected in the wild (Siqueiros Beltrones, 2002; Siqueiros Beltrones et al., 2004; Siqueiros Beltrones et al., 2005). Thus our intention to determine what diatom taxa would be found on other macroalgae, such as $E$. arborea, which represents the ecological alternative for $M$. pyrifera in the region. The assumption that $E$. arborea blades may be grazed by abalone is supported by recent experiments that show that abalone juveniles from the region successfully feed on E. arborea (Mazariegos-Villarreal et al., 2012). 
Knowing the taxonomic identity of the main epiphytic diatoms that are being ingested by Haliotis spp. together with their hosts offers an alternative to a better management of abalone under culture conditions. It should also prompt studies on the nutritious properties of these taxa in order to pinpoint their specific role in the diet of the many grazers that depend on them.

\section{ACKNOWLEDGEMENTS}

This study was financed through project SIP: 20141095, and kelp blades were acquired through project SIP: 20140968 (Instituto Politécnico Nacional). We thank A. Witkowski for correcting our previous misidentification of Pteroncola inane. We gratefully acknowledge the elegant and assertive reviews by two anonymous referees. Yuriko Martínez edited figure 1. The first author is a COFAA and EDI fellow. The third author was sponsored by BEIFI in the latter project.

\section{REFERENCES}

Argumedo-Hernández, U. \& D. A. Siqueiros-Beltrones. 2008. Cambios en la estructura de la asociación de diatomeas epífitas de Macrocystis pyrifera (L.) C. Ag. Acta Botánica Mexicana 82: 43-66.

Cleve-Euler, A. 1968. Die Diatomeen von schweenden un finnland. In: Verlag von Kramer, Bibliotheca Phycologica, Band 5. Wheldon y Wesley, N.Y. I-V, 963 p.

Desikachary, T. V. 1988. Atlas of diatoms. Fasc. IV. Madras Sci. Foundation, India. $13 \mathrm{p}$.

Hendey, I. N. 1964. An introductory account of the smaller algae of British coastal waters. Part V: Bacillariophyceae (Diatoms). Fishery Investigation. Series IV. HMSO. Londres. 317 p.

Hernández-Carmona, G., S. Carrillo-Domínguez, D. L. Arvizu-Higuera, Y. E. Rodríguez-Montesinos, J. I. Murillo-Álvarez, M. Muñoz-Ochoa \& R. M. Castillo-Dominguez. 2009. Monthly variation in the chemical composition of Eisenia arborea J. E. Areschoug. Journal of Applied Phycology 21: 607-616.

Hustedt, F. 1959. Die kieselalgen Deutschlands, Osterreichs and der Schweis. In: L. Rabenhorts (Ed.), Kryptogammen-Flora. VII Band, II Teil. Koeltz Scientific Book (reimp. 1991). Leipzig. 845 p.

Hustedt, F. 1961-66. Die kieselalgen Deutschlands, Osterreichs and der Schweis. In: L. Rabenhorts (Ed.) Kryptogammen-Flora. VII Band, III Teil. Koeltz Scientific Book (reimp. 1991). Leipzig. 916 p.

López-Fuerte, F. O., D. A. Siqueiros-Beltrones \& E. Novelo-Maldonado. 2010. Benthic diatoms associated with mangrove environments in the northwest region of Mexico. CONABIO-UAB.C.S.-IPN, La Paz, México. $206 \mathrm{p}$.

Mazariegos-Villarreal, A., M. Casas-Valdéz, D. A. Siqueiros-Beltrones, A. Piñón-Gimate \& E. Serviere-Zaragoza. 2012. Changes in the natural diet of green abalone (Haliotis fulgens Philippi 1845), during the 1997-1998 ENSO, in Baja California Sur, Mexico. Journal of Shellfish Research 31 (3): 795-800.

Peragallo, H. \& M. Peragallo. 1908. Diatomees marines de France et des districts marines voisins. M. J. Tempere, France. 491 p.

Pedroche, F. F., P. C. Silva, L. E. Agullar Rosas, K. M. Dreckman \& R. Aguilar RosAs. 2008. Catálogo de las algas marinas bentónicas del Pacífico mexicano II. Phaeophycota. Universidad Autónoma Metropolitana, Universidad Autónoma de Baja California, Universidad de California Berkeley. México, D.F. 146 p

Round, F. E., R. M. Crawford \& D. G. Mann. 1990. The Diatoms. Cambridge University Press. Cambridge. 747 p.

Schmidt, A., M. Schmidt, F. Fricke, H. Heiden, 0. Muller \& F. Hustedt. 18741959. Atlas der diatomaceenkunde. Heft 1-120, Tafeln 1-460. Reisland, Leipzing. 208 p.

Siqueiros Beltrones, D. A. 2002. Diatomeas bentónicas de la Península de Baja California; diversidad y potencial ecológico. Oceánides/ CICIMAR-IPN/UAB.C.S.. 102 p. ISBN 970-18-7595-8.

Siqueiros-Beltrones, D. A. \& U. Argumedo-Hernández. 2005. Florística de diatomeas epifitas en láminas apicales de Macrocystis pyrifera (L.) C. Ag. CICIMAR-Oceánides 20: 37-63.

Siqueiros-Beltrones, D. A. \& U. Argumedo-Hernández. 2014a. Particular structure of an epiphytic diatom assemblage living on Ploclamium cartilagineum (Lamoroux) Dixon (Rhodophyceae: Gigartinales). CICIMAR-Oceánides 29 (2): 11-24.

Siqueiros-Beltrones, D. A. \& U. Argumedo Hernández. 2014b. Quasi monospecific proliferation of Pteroncola inane (Giffen) Round (Fragilariales; Bacillariophyceae) on blades of Eisenia arborea Areschoug. CICIMAR-Oceánides 29 (2): 57-62.

Siqueiros-Beltrones, D. A. \& 0. U. Hernández-Almeida. 2006. Florística de diatomeas epifitas en macroalgas de un manchón subtropical. CICIMAR-Oceánides 21: 11-61.

Siqueiros-Beltrones, D. A. \& F. 0. López Fuerte. 2006. Benthic diatoms associated to red mangrove (Rhizophora mangle L.) prop roots in Bahia Magdalena, B.C.S, México. Biología Tropical 54 (2): 287-297.

Siqueiros Beltrones, D. A. \& G. Valenzuela Romero. 2001. New records of benthic diatoms from natural grazing surfaces of abalone (Haliotis spp.) habitats in the Baja California peninsula. Oceanides 16 (2): 107-126.

Siqueiros-Beltrones, D. A. \& G. Valenzuela-Romero. 2004. Benthic diatom assemblages in an Abalone (Haliotis spp) Habitat in the Baja California Peninsula. Pacific Science 58: 435-446

Siqueiros-Beltrones, D. A., E. Serviere-Zaragoza \& U. Argumedo-Hernández. 2002. Epiphytic diatoms of Macrocystis pyrifera (L.) Ag. from the Baja California peninsula. Oceánides 17: 3-39.

Siqueiros-Beltrones, D. A., G. Valenzuela-Romero, 0. Hernández-Almeida, U. Argumedo-Hernández \& F. 0. López-Fuerte. 2004. Catálogo iconográfico de diatomeas de hábitat rocosos y su incidencia en la dieta de abulones (Haliotis spp.) jóvenes de Baja California Sur, México. CICIMAR-Oceánides 19: 1-79.

Siqueiros-Beltrones, D. A., E. Serviere-Zaragoza \& S. Guzmán del Próo. 2005. Main diatom taxa in the natural diet of juvenile Haliotis fulgens and H. corrugata (Mollusca: Gastropoda) from Bahía Tortugas and Bahía Asunción, B.C.S., México. Pacific Science 59: 581-592.

Witkowski, A., H. Lange-Bertalot \& D. Metzeltin. 2000. Diatom flora of Marine coast I. A.R.G. Gantner Verlag K.G., Ruggell. 925 p.

Recibido: 18 de diciembre de 2014

Aceptado: 23 de noviembre de 2015. 